\title{
OBSERVATIONS ON THE CHEMICAL PATHOLOGY OF THE BLOOD IN PERNICIOUS ANEMIA AND OTHER SEVERE ANEMIAS *
}

\author{
Amos W. PETERS, Ph.D., And A. S. RUBnitZ, M.D. \\ OMAHA
}

INTRODUCTION

This study is confined to fundamental chemical conditions of the blood in pernicious and severe secondary anemia and, for comparison, to a study of the same conditions in one series of normal subjects and in another series of pathologic conditions other than anemias. We found early in our study that the total blood solids in clearly diagnosed cases of pernicious anemia were extraordinarily low. From the comparison series above mentioned it appeared that so great an abnormal deviation is so uncommon an occurrence in other pathologic conditions as to make extremely low blood solids one of the pathologic characteristics of pernicious anemia and severe secondary anemia. Further observation showed marked deviation from normal values in the total nitrogen of the whole blood in this condition but a much less pronounced deviation in the total nitrogen of the plasma. However, on studying the ratio of the whole blood nitrogen to the total nitrogen of the plasma a relation ("index" in column 7 of Tables 1, 2 and 3) appeared that is also a pathologic characteristic of severe anemia. There is reason to believe that this abnormal index and the excessively low blood solids are as constantly associated chemical conditions of severe anemias as the low red cell count is characteristic of the morphology of this blood. We regard the present study as introductory and we are making further observations on these conditions.

\section{METHODS}

The methods used were an application of the principles developed in a previous publication ${ }^{1}$ but some deviations from the technic there described and some corrections were made. There is also added the following method for the determination of total plasma nitrogen, which obviates the difficulty of separating such small amounts of plasma as are here used, from corpuscles. The technic for blood solids was used as described. ${ }^{2}$

* From the Biochemical Laboratory of the University of Nebraska College of Medicine, and the University Hospital.

1. Peters, Amos W.: The Micro Determination of Nitrogen by Direct Nesslerization and of Total Solids, in Drop Quantities of Human Blood, J. Biol. Chem. 39:285, 1919. 
For whole blood and plasma nitrogen the blood was collected in one weighed and stoppered test tube containing exactly 12 c.c. of fluorid-salt solution of the following composition: sodium fluorid, 3.5 gm. ; sodium chlorid, $5.0 \mathrm{gm}$. per 1,000 c.c. distilled water. The alkalinity to phenolphthalein of 1,000 c.c. or more should be neutralized by adding concentrated hydrochloric acid, one drop at a time, until a test remains colorless with the indicator. Enough of the 10 per cent. sodium hydroxid used elsewhere in these methods should then be added drop by drop from the buret to just restore the alkalinity to phenolphthalein as found on a test sample of the medium. Without the precaution of regulating the reaction of the fluorid-salt medium the results obtained for plasma nitrogen might be vitiated entirely by solution or extraction of corpuscles. The first two drops of finger blood and no subsequent ones, were received in the previously described test tube which was then reweighed to ascertain by difference the weight of the blood. From this total volume two aliquots of 2 c.c. each, designated A 1 and A 2, respectively, were removed for the determination of the total nitrogen of the whole blood. Care should be taken to mix thoroughly the contents before each aliquot is taken in order to avoid error from partial sedimentation of corpuscles, which occurs rapidly. The remaining volume is transferred to a conical centrifuge tube and centrifuged thirty minutes. The clear and nearly always colorless liquid is decanted from the corpuscles into another tube from which 5 c.c., designated as AA, is removed for the determination of the total nitrogen of the plasma. This 5 c.c. is, of course, an aliquot of the original volume.

The two drops of blood usually weigh from 50 to $70 \mathrm{mg}$., and the total volume of the original blood dilution may be taken at e. $g$. $\mathrm{V}=12.07$ c.c., from which aliquots of $2 . / 12.07$ and 5./12.07 have been taken of the weight of the two drops of blood.

If a nonprotein determination is also desired, the ten or more drops of finger blood next following the first two are received in about 10 c.c. of distilled water (not in sodium fluorid solution as directed in the previous publication ${ }^{1}$ ) and this is designated as $\mathrm{B}$. The tube for total solids being designated as $\mathrm{C}$, an entire set of determinations consist of A 1, A 2, AA, B and C. The nitrogen in A $1, A 2$ and AA is determined as previously described ${ }^{1}$ except as the following modifications have much improved the process.

All neutralized unknown solutions that are to be nesslerized are first made to a volume of 40 c.c. in a 100 c.c. cylinder, from which the liquid is delivered into 10 c.c. of the below described Nessler solution, which has been measured with a volumetric pipet into a carbon dioxid flask. The final volume is thus 50 c.c. without further 
measurement or transfer and the Nessler reaction always occurs under comparable conditions of concentration. When a series of determinations is to be made it is advantageous to let the several cylinders, each made to a volume of 40 c.c., stand in a row, with carbon dioxid flask with the measured 10 c.c. of Nessler standing beside each, until the operator is ready to do the whole series of nesslerizations and colorimetric readings in order.

The modified Nessler reagent is made by mixing 200 c.c. of the Folin ${ }^{2}$ potassium-mercuric iodid stock solution with 100 c.c. of 10 per cent. sodium hydroxid and 200 c.c. of distilled water. With this modification the progressive change in color immediately after mixing as above is less rapid. By making the colorimetric reading against the permanent color standard, in the interval between four and seven minutes after mixing, the agreement between duplicates on the same reagents can be kept within a few tenths of a millimeter. Duplicates on blood also show exceedingly small deviations.

TABLE 1.-Normal Human Blood

\begin{tabular}{|c|c|c|c|c|c|c|}
\hline $\begin{array}{c}1 \\
\text { Blood } \\
\text { No. }\end{array}$ & $\begin{array}{c}2 \\
\text { Subject } \\
\text { No. }\end{array}$ & $\begin{array}{c}3 \\
\text { Date }\end{array}$ & $\begin{array}{c}4 \\
\text { Solids, } \\
\text { per Cent. }\end{array}$ & $\begin{array}{c}5 \\
\text { Whole } \\
\text { Blood N, } \\
\text { per Cent. }\end{array}$ & $\begin{array}{c}6 \\
\text { Plasma N, } \\
\text { per Cent. }\end{array}$ & $\frac{\begin{array}{c}7 \\
\text { Index } \\
\text { Whole Blood N \% }\end{array}}{\text { Plasma N \% }}$ \\
\hline $\begin{array}{r}1 \\
2 \\
3 \\
38 \\
42 \\
45 \\
46 \\
47 \\
59 \\
60 \\
48 \\
49 \\
50 \\
51 \\
57 \\
58 \\
61 \\
62 \\
52 \\
53 \\
54 \\
55\end{array}$ & $\begin{array}{l}1 \\
1 \\
1 \\
1 \\
1 \\
2 \\
2 \\
2 \\
2 \\
2 \\
3 \\
3 \\
3 \\
3 \\
3 \\
3 \\
3 \\
3 \\
4 \\
4 \\
4 \\
5\end{array}$ & $\begin{array}{c}10 / 7 / 19 \\
10 / 27 / 19 \\
11 / 11 / 19 \\
12 / 24 / 19 \\
5 / 6 / 20 \\
6 / 1 / 20 \\
6 / 4 / 20 \\
6 / 29 / 20 \\
7 / 2 / 20 \\
7 / 13 / 20 \\
6 / 3 / 20 \\
6 / 9 / 20 \\
6 / 25 / 20 \\
6 / 30 / 20 \\
7 / 2220 \\
7 / 2 / 20 \\
7 / 10 / 20 \\
7 / 13 / 20 \\
6 / 8 / 80 \\
6 / 25 / 20 \\
6 / 30 / 20 \\
6 / 16 / 20\end{array}$ & $\begin{array}{l}20.6 \\
20.3 \\
20.8 \\
\ldots . . \\
\ldots . \\
\ldots . . \\
\ldots . \\
\ldots . . \\
\ldots . . \\
\ldots . \\
\ldots 2.6 \\
\ldots .6 \\
19.1 \\
22.4 \\
18.8 \\
\ldots 2.8 \\
22.8 \\
\ldots . \\
\end{array}$ & $\begin{array}{l}3.16 \\
3.48 \\
3.00 \\
3.34 \\
2.78 \\
3.18 \\
3.29 \\
2.88 \\
2.83 \\
3.26 \\
3.33 \\
3.36 \\
2.73 \\
2.90 \\
2.73 \\
2.84 \\
2.65 \\
2.85 \\
3.22 \\
3.14 \\
2.94 \\
3.15\end{array}$ & $\begin{array}{l}0.74 \\
0.66 \\
0.60 \\
0.81 \\
0.88 \\
0.82 \\
0.83 \\
0.96 \\
0.78 \\
1.05 \\
1.14 \\
1.03 \\
0.92 \\
\\
1.08 \\
1.06 \\
0.85 \\
1.06 \\
0.82 \\
0.92 \\
1.13\end{array}$ & $\begin{array}{l}4.7 \\
4.5 \\
5.6 \\
3.4 \\
3.6 \\
4.0 \\
3.5 \\
2.9 \\
4.2 \\
3.2 \\
2.9 \\
2.7 \\
3.2 \\
\\
2.6 \\
2.5 \\
3.4 \\
3.0 \\
3.8 \\
3.2 \\
2.8\end{array}$ \\
\hline \multicolumn{6}{|c|}{ 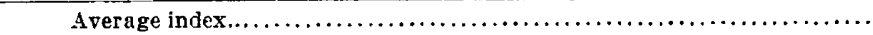 } & $3 . \overline{5}$ \\
\hline
\end{tabular}

The same stock quantity of distilled water and the same stock of reagents should be used throughout a given series of determinations that are to be calculated by means of a given base value $(0.35$ $\mathrm{mg} . \mathrm{N})$. It is well worth noting from the standpoint of accuracy in dealing with such small amounts of nitrogen as are used that this base value always functions as a blank on the reagents, including the distilled water, as well as being the base of calculation.

2. Folin, O., and Dennis, W.: Nitrogen Determination by Direct Nesslerization. I. Total Nitrogen in Urine, J. Biol. Chem. 26:479, 1916. Folin, O., and Hsien, Wu: A System of Blood Analysis, J. Biol. Chem. 38:89, 1919. 
Pebbles or other means to prevent bumping during the digestions have been found unnecessary except for nonprotein nitrogen.

The value of $R$ used in the calculation of the colorimetric reading into mg. of nitrogen was determined for each series of unknowns by comparing the results of a single test each on $0.35 \mathrm{mg}$. and 0.15 mg. standard nitrogen.

With the above modifications we have found the use of a single constant color standard, which is the special characteristic of this method, not only accurate as previously described, but also quite expeditious when many determinations were to be made as in these experiments. This is due to the elimination of the time and labor consumed in the customary procedure of making a fresh standard for each and every determination.

TABle 2.-Blood in Pernicious Anemia and in Secondary Anemia

\begin{tabular}{|c|c|c|c|c|c|c|c|}
\hline $\begin{array}{l}1 \\
\text { Blood } \\
\text { No. }\end{array}$ & $\begin{array}{l}2 \\
\text { Case } \\
\text { No. }\end{array}$ & $\begin{array}{c}3 \\
\text { Date }\end{array}$ & $\begin{array}{c}4 \\
\text { Solids, } \\
\text { per Cent. }\end{array}$ & $\begin{array}{c}5 \\
\text { Whole } \\
\text { Blood N, } \\
\text { per Cert. }\end{array}$ & $\begin{array}{c}6 \\
\text { Plasma } \\
\text { N. } \\
\text { ver Cent. }\end{array}$ & $\frac{\begin{array}{c}7 \\
\text { Index }\end{array}}{\text { Whole Blood N \% }}$ & $\begin{array}{c}\mathrm{S} \\
\text {. Diagnosis }\end{array}$ \\
\hline $\begin{array}{l}15 \\
16 \\
17 \\
18 \\
19 \\
20 \\
21 \\
35 \\
36 \\
39 \\
44 \\
65 \\
23 \\
40 \\
41 \\
63\end{array}$ & $\begin{array}{l}1 \\
1 \\
1 \\
1 \\
2 \\
2 \\
2 \\
2 \\
3 \\
3 \\
3 \\
3 \\
3 \\
4 \\
5 \\
6 \\
7\end{array}$ & $\begin{array}{r}10 / 9 / 19 \\
10 / 11 / 19 \\
10 / 18 / 19 \\
10 / 29 / 19 \\
11 / 1 / 19 \\
11 / 4 / 19 \\
11 / 4 / 19 \\
12 / 9 / 19 \\
12 / 11 / 19 \\
12 / 27 / 19 \\
5 / 20 / 20 \\
7 / 17 / 20 \\
11 / 18 / 19 \\
4 / 27 / 20 \\
4 / 30 / 20 \\
7 / 16 / 20 \\
7 / 21 / 20\end{array}$ & $\begin{array}{r}13.0 \\
12.7 \\
13.2 \\
12.0 \\
12.6 \\
12.6 \\
13.5 \\
8.0 \\
9.8 \\
10.1 \\
11.6 \\
14.7 \\
14.5 \\
\ldots .0 \\
9.0 \\
12.3 \\
13.6\end{array}$ & $\begin{array}{l}2.34 \\
1.77 \\
2.10 \\
2.12 \\
1.99 \\
2.03 \\
1.97 \\
1.34 \\
1.43 \\
1.29 \\
2.00 \\
2.17 \\
2.70 \\
1.38 \\
2.16 \\
2.25 \\
\\
2.37\end{array}$ & $\begin{array}{l}1.14 \\
1.19 \\
1.25 \\
0.99 \\
0.82 \\
1.05 \\
0.90 \\
0.73 \\
0.76 \\
\\
1.09 \\
0.97 \\
1.01 \\
1.02 \\
0.74 \\
1.04\end{array}$ & $\begin{array}{l}1.6 \\
1.8 \\
1.7 \\
2.0 \\
2.5 \\
1.9 \\
1.5 \\
2.0 \\
1.7 \\
\\
2.7 \\
2.8 \\
1.4 \\
2.1 \\
3.0 \\
\\
2.2\end{array}$ & $\begin{array}{l}\text { Pernicious anemia } \\
\text { and syphilis } \\
\begin{array}{l}\text { Chronie secondary } \\
\text { anemia }\end{array} \\
\text { Pernicious anemia } \\
\text { Pernicious anemia } \\
\text { Pernicious anemia } \\
\text { Secondary anemia } \\
\text { Exophthalmic goiter } \\
\text { and sec. anemia } \\
\text { Suspected pernicious } \\
\text { anemia }\end{array}$ \\
\hline \multicolumn{6}{|c|}{ 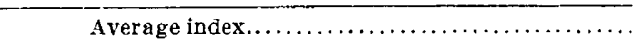 } & 2.1 & \\
\hline
\end{tabular}

CLINICAL DATA ON CASES IN TABLE 2

The clinical data recorded below were primarily intended to present only the salient pathologic conditions that might stand in relation to the factor of anemia. We, however, doubt that such a selection is justifiable in view of the possible interrelations of all pathologic conditions in the same subject. We have, nevertheless, selected the trio of conditions that are commonly regarded as constituting the essentials of the syndrome of pernicious anemia, i. e., the blood count, the gastro-intestinal-abdominal findings and the neurologic factor. These include the low red cell count, the achlorhydria, and the evidences of cord degeneration, all of which, it should be remembered, need not be concurrent, especially the cord symptoms. After having 
made this selection, and after some reflection on what might be the consequences of the conditions revealed by the laboratory findings, we were much impressed by the almost constant finding, in the physical examination, of more or less pronounced edema in nearly all these anemia cases whether pernicious or secondary. Minor functional but not organic cardiac symptoms and a palpable liver and spleen were practically constant concomitants of the edemas. Whether these edemas are to be regarded as primarily due to mechanical, obstructive factors or to chemical alterations of blood composition or of vascular endothelium is not answered by our present study

Table 3.-Human Blood in Pathologic Conditions (Other Than Pernicious Anemia)

\begin{tabular}{|c|c|c|c|c|c|c|}
\hline $\begin{array}{c}1 \\
\text { Blood } \\
\text { No. }\end{array}$ & $\begin{array}{c}2 \\
\text { Case } \\
\text { No. }\end{array}$ & $\begin{array}{c}3 \\
\text { Date }\end{array}$ & $\begin{array}{c}4 \\
\text { Solids, } \\
\text { per Cent. }\end{array}$ & $\begin{array}{c}5 \\
\text { Whole } \\
\text { Blood N, } \\
\text { per Cent. }\end{array}$ & $\begin{array}{c}6 \\
\text { Plasma N, } \\
\text { per Cent. }\end{array}$ & $\frac{\begin{array}{c}7 \\
\text { Index } \\
\text { Whole Blood N \% }\end{array}}{\text { Plasma N \% }}$ \\
\hline $\begin{array}{r}13 \\
14 \\
26 \\
4 \\
5 \\
6 \\
7 \\
8 \\
9 \\
10 \\
11 \\
12 \\
31 \\
37 \\
24 \\
43 \\
56\end{array}$ & $\begin{array}{r}1 \\
2 \\
3 \\
4 \\
4 \\
4 \\
4 \\
5 \\
5 \\
5 \\
5 \\
6 \\
7 \\
7 \\
8 \\
9 \\
10\end{array}$ & $\begin{array}{r}11 / 15 / 19 \\
11 / 13 / 19 \\
12 / 11 / 19 \\
9 / 30 / 19 \\
10 / 7 / 19 \\
10 / 16 / 19 \\
10 / 24 / 19 \\
10 / 2 / 19 \\
10 / 3 / 19 \\
10 / 14 / 19 \\
10 / 22 / 19 \\
10 / 29 / 19 \\
12 / 16 / 19 \\
12 / 18 / 19 \\
11 / 20 / 19 \\
5 / 20 / 20 \\
7 / 9 / 20\end{array}$ & $\begin{array}{l}10.3 \\
16.0 \\
18.4 \\
18.0 \\
18.9 \\
18.8 \\
18.0 \\
18.8 \\
18.8 \\
19.3 \\
15.7 \\
20.9 \\
19.0 \\
20.4 \\
18.4 \\
17.5\end{array}$ & $\begin{array}{l}1.29 \\
3.21 \\
2.74 \\
2.71 \\
2.27 \\
2.78 \\
3.15 \\
2.75 \\
2.74 \\
2.80 \\
3.12 \\
2.31 \\
3.30 \\
2.63 \\
2.91 \\
3.13 \\
2.70\end{array}$ & $\begin{array}{l}0.81 \\
0.98 \\
0.64 \\
0.66 \\
0.65 \\
0.76 \\
\\
0.64\end{array}$ & $\begin{array}{l}3.5 \\
3.2 \\
3.6 \\
5.0 \\
4.0 \\
4.0 \\
\\
4.2\end{array}$ \\
\hline \multicolumn{6}{|c|}{ 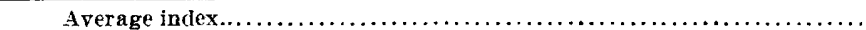 } & 3.8 \\
\hline
\end{tabular}

All hemoglobin determinations were made according to Sahli.

Differential blood counts were used in making the diagnosis of pernicious anemia.

\section{REPORT OF CASES}

CASE 1.-Male, half Indian, half Mexican, aged 40 .

Diagnosis.-Pernicious anemia and syphilis.

Blood Counts:

\begin{tabular}{|c|c|c|c|}
\hline $\begin{array}{l}\text { Date } \\
1919\end{array}$ & $\begin{array}{l}\text { Hemoglobin, } \\
\text { Per Cent. }\end{array}$ & $\begin{array}{l}\text { Red Blood } \\
\text { Cells }\end{array}$ & Leukocyt \\
\hline June $5 .$. & 20 & 800,000 & 4,600 \\
\hline June $6 .$. & 18 & 770,000 & 2.950 \\
\hline June $18 \ldots$ & 20 & 870,000 & 6,500 \\
\hline June 26. . & 19 & 830,000 & 4,500 \\
\hline July $8 \ldots$ & 36 & $1,460,000$ & 2,600 \\
\hline July $21 \ldots$ & 35 & $1,900,000$ & 2,100 \\
\hline July $31 .$. & 28 & $2,150,000$ & 4,500 \\
\hline Aug. $26 \ldots \ldots \ldots \ldots$ & 46 & $2 ; 600,000$ & 3,700 \\
\hline Sept. $\quad 6 \ldots \ldots \ldots \ldots \ldots$ & 60 & $1,780,000$ & $\ldots .$. \\
\hline Oct. $\quad 5 \ldots \ldots \ldots \ldots \ldots$ & 40 & 870,000 & \\
\hline Oct. $14 .$. & . & $1,700,000$ & ..... \\
\hline Nov. 25 . & 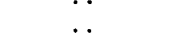 & $1,456,000$ & ..... \\
\hline
\end{tabular}


Gastro-Intestinal and Abdominal Symptoms.-Epigastric pain; sour stomach; constipation; fluid in peritoneal cavity, moves to dependent portion, fluctuates; liver palpable three fingers' width below costal margin; hepatic region very tender.

Neurologic Symptoms.-Practically negative.

Case 2.-Male, Mexican, aged 38.

Diagnosis.-Chronic secondary anemia.

Blood Counts:

$\begin{array}{cccc}\begin{array}{l}\text { Date } \\ 1919\end{array} & \begin{array}{c}\text { Hemoglobin, } \\ \text { Per Cent. }\end{array} & \begin{array}{c}\text { Red Blood } \\ \text { Cells }\end{array} & \text { Leukocytes } \\ \text { Oct. } 30 \ldots \ldots \ldots \ldots \ldots & 50 & 1,640,000 & 7,700 \\ \text { Nov. } 2 \ldots \ldots \ldots \ldots \ldots & 45 & 2,700,000 & 8,400 \\ \text { Nov. } 7 \ldots \ldots \ldots \ldots \ldots & 45 & 2,200,000 & 8,100 \\ \text { Nov. } 8 \ldots \ldots \ldots \ldots \ldots & . & \ldots \ldots \ldots \ldots & 7,000 \\ \text { Nov. } 20 \ldots \ldots \ldots \ldots \ldots & 55 & 2,464,000 & 15,500 \\ \text { Nov. } 25 \ldots \ldots \ldots \ldots \ldots & \ldots & 3,160,000 & \ldots \ldots\end{array}$

Gastro-Intestinal and Abdominal Symptoms.-Practically negative.

Neurologic Symptoms.-Negative.

CASE 3.--Male, American, aged 50.

Diagnosis.-Pernicious anemia.

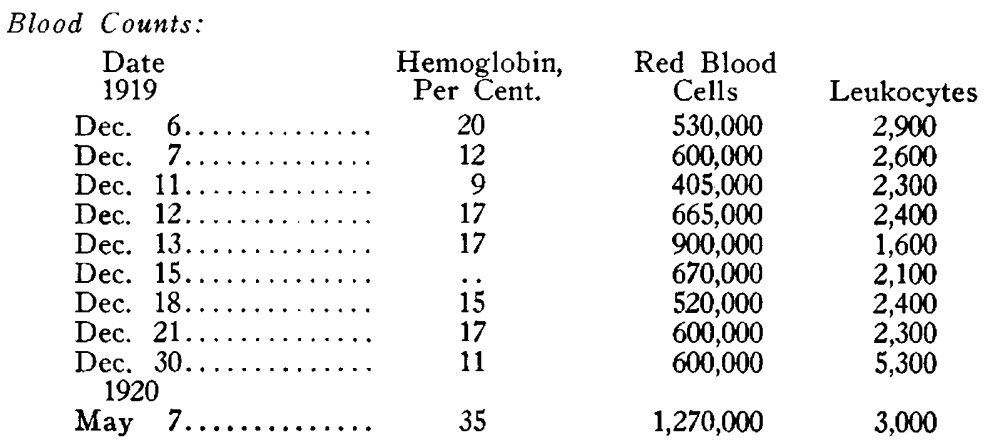

Gastro-Intestinal and Abdominal Symptoms.-Pain, nausea, vomiting at times; constipation; tenderness in region of gallbladder; abdomen full and rounded, highly tympanitic; no fluid; liver above costal margin; spleen palpable.

Neurologic Symptoms.-Pain and twitching of legs and arms, numbness; progressive weakness until unable to stand or walk; knee jerks exaggerated; ankle clonus present; Babinski positive.

CASE 4.-Female, German, aged 40.

Diagnosis.-Pernicious anemia.

CASE 5.-Female, American, aged 32.

Diagnosis.-Pernicious anemia.

Blood Counts:

$\begin{array}{lccc}\begin{array}{l}\text { Date } \\ 1920\end{array} & \begin{array}{c}\text { Hemoglobin, } \\ \text { Per Cent. }\end{array} & \begin{array}{c}\text { Red Blood } \\ \text { Cells }\end{array} & \text { Leukocytes } \\ \text { April } 13 \ldots \ldots \ldots \ldots \ldots & 15 & 640,000 & 6,000 \\ \text { April } 15 \ldots \ldots \ldots \ldots \ldots & 20 & 710,000 & 5,000 \\ \text { April } 25 \ldots \ldots \ldots \ldots \ldots & 15 & 680,000 & 4,200 \\ \text { May } 7 \ldots \ldots \ldots \ldots \ldots & 25 & 980,000 & 3,400\end{array}$


Gastro-Intestinal and Abdominal Symptoms.-Pain and bloating; abdomen very tender; constipation; achlorhydria; mass extending from epigastrium below right costal border, apparently the liver; spleen palpable about 1 inch below costal margin.

Neurologic Symptoms.-Practically negative.

CASE 6.-Male, American, aged 39.

Diagnosis.-Secondary anemia.

Blood Counts:

$\begin{array}{cccc}\begin{array}{c}\text { Date } \\ 1920\end{array} & \begin{array}{c}\text { Hemoglobin, } \\ \text { Per Cent. }\end{array} & \begin{array}{c}\text { Red Blood } \\ \text { Cells }\end{array} & \text { Leukocytes } \\ \text { April } 22 \ldots \ldots \ldots \ldots \ldots & 32 & 2,800,000 & 5,000 \\ \text { May } 4 \ldots \ldots \ldots \ldots \ldots & 38 & 3,180,000 & \ldots \ldots\end{array}$

Gastro-Intestinal and Abdominal Symptoms.-Practically negative.

Neurologic Symptoms.-Practically negative.

CASE 7.-Female, American, aged 37.

Diagnosis.-Exophthalmic goiter: secondary anemia.

Blood Count:

\begin{tabular}{|c|c|c|}
\hline $\begin{array}{l}\text { Date } \\
1920\end{array}$ & $\begin{array}{l}\text { Hemoglobin, } \\
\text { Per Cent. }\end{array}$ & $\begin{array}{l}\text { Red Blood } \\
\text { Cells }\end{array}$ \\
\hline July $1 \ldots \ldots \ldots \ldots \ldots$ & 60 & $3,200,000$ \\
\hline
\end{tabular}

Gastro-Intestinal and Abdominal Symptoms.-Appetite poor; diarrhea; free hydrochloric acid. Abdomen: no masses; no rigidity; no tenderness; liver enlarged, palpable $2 \mathrm{~cm}$. below costal margin; spleen enlarged, palpable.

Neurologic Symptoms.-Dizziness; nervousness; insomnia.

\section{DISCUSSION OF RESULTS}

A comparison of Columns 4 in the three tables shows that an extreme decrease in the total solids of the whole blood is one of the prominent characteristics of a severe anemia. The normal values as shown by Table 1 may be taken to range approximately from 19 to 22 per cent. and similar or slightly lower values are found in hospital cases other than severe anemias as shown by Table 3 . These latter data are of importance in showing that it is the anemia and not other possible metabolic derangement that is responsible for the low values of Table 2. These values in pernicious anemia are so low that if they represented only or principally change in chemical composition of the blood we should expect fatal physiologic consequences. Evidently, it is the outstanding characteristic alteration of severe anemia-the decrease in the number of red corpuscles-that is responsible for the low value of the total solids. A study of the clinical data confirms this proposition. We should, however, note carefully that the possibility of considerable change in the chemical composition of the blood is not to be excluded from the conditions which prevail in severe anemia. We shall report further on these and related questions in the near future. 
We then have in the diminution of total solids a chemical representation of that characteristic of anemia which has heretofore been represented only by morphologic data, i. e., the red cell count.

A comparison of Columns 5 in the three tables shows that the total nitrogen of the whole blood comports itself similarly to the total solids, showing very low values for pernicious and severe secondary anemias. In this respect also the values of Table 3 for other pathologic conditions show more deviation from the normal level of Table 1 than the solids showed. This might be expected from the almost universal presence of the anemic factor in practically all pathologic conditions. A comparison of the clinical data leads us here also to attribute the decrease in nitrogen content primarily and principally but not wholly to the low red cell count. The question is very justly raised here whether part of this result may not be due to decrease in plasma nitrogen as well as to diminished number of red corpuscles. That changes in the albumin and globulin content either absolute or relative should occur in severe anemia is both possible and probable. However, the results shown by Columns 6 of the three tables fail to show a decrease in the plasma nitrogen whether the subjects be anemic or otherwise affected. On the contrary, if the plasma nitrogen undergoes any change in the pathologic conditions represented it is in the direction of increased concentration of nitrogen. We may, with some justice, attribute this tendency to the retention of waste nitrogenous products or to altered osmotic equilibria, both of which probably occur in most pathologic conditions. Provisionally, until we have made further investigations, we believe it to be a plausible proposition that the plasma interposes, for physiologic reasons, great resistance to a diminution in its nitrogen concentration, and we believe that plasma nitrogen concentrations that approach 1 per cent. are pathologic. In this connection it should be noted that the reaction of the collection medium from which the corpuscles are centrifuged should be controlled carefully, either as previously described or otherwise, in order to avoid erroneously high results for the plasma nitrogen due to solution of some corpuscles or to extraction of nitrogenous substances from the corpuscles between the time of collection and that of decantation.

We have, then, in the whole blood nitrogen, as well as in the solids, a chemical representation of the morphologic characteristic of low red cell count. We have tested experimentally on various physiologic and pathologic conditions in human subjects the reliability of this chemical expression for anemic conditions with (unpublished) results that are fully confirmatory.

It is now possible to study the quantitative relations between the whole blood nitrogen and the plasma nitrogen since the direction 
of variation of each is known. When the whole blood nitrogen undergoes pathologic change it always decreases in anemia, and we have seen that the plasma nitrogen either holds its normal value or increases. The direction variation is such that the ratio $\frac{\text { Whole Blood } \mathrm{N}, \%}{\text { Plasma } \mathrm{N}, \%}$ under pathologic conditions diminishes since the numerator decreases and the denominator increases or remains constant. This ratio we will call nitrogen index and it is clear that as an anemia becomes more severe this index becomes smaller. The three tables adequately show how well this index expresses these pathologic conditions as well as physiologic normality.

\section{SUMMARY}

1. Human blood from three series of persons has been examined for its concentration in $(a)$ total solids, $(b)$ total nitrogen in whole blood, $(c)$ total nitrogen in plasma. The first series comprised physio. logically normal persons, the second cases of pernicious anemia and severe secondary anemia, the third cases of various pathologic conditions other than severe anemia.

2. A method has been described for the determination of plasma nitrogen in very small amounts of blood whereby plasma and corpuscles are separated after dilution.

3. The total solids of the blood of pernicious anemia and also of severe secondary anemia show great decrease from normal values or even from that of other chronic hospital cases. This decrease is due primarily to the large diminution in number of the red corpuscles and only in minor degree to decrease in plasma solids.

4. The total nitrogen of the whole blood in pernicious anemia and also in severe secondary anemias shows, like the total solids, a great decrease from the normal values. The principal cause here also is diminution in the number of the red corpuscles.

5. The percentage of total solids and of whole blood nitrogen are the essential chemical correlates of the number of red corpuscles, i. e., there is a marked proportionality in these two independently determinable factors.

6. The total plasma nitrogen in contradistinction to the total blood nitrogen either maintains its normal limits of constancy or tends to increase in percentage above that of most normal bloods, but in any case it has no tendency to decrease its nitrogen value.

7. Since in all severe anemic conditions the whole blood nitrogen decreases while the plasma nitrogen tends to increase, the resultant ratio of the first to the second, which constitutes a nitrogen index, shows from the direction of variation in both factors a natural tendency to diminish in proportion to the severity of the anemia. This index may be used as an indicator of the state and progress of the anemic condition. 